\title{
An Empirical Analysis of the Relationship Between Farmers' Income and Economic Growth in Fujian
}

\author{
Qinping Chen \\ Fuzhou University of International Studies and Trade \\ Fuzhou, China
}

\begin{abstract}
Increasing the income of peasants is the key to resolve the problems of peasants, countryside and agriculture. It is not only related to the interests of farmers and rural development, but also directly related to the overall situation of social stability and national economic development. Therefore, how to fundamentally solve the problem of farmers' income growth is still very worthy of attention and research. Taking Fujian Province as an example, the paper uses logarithmiclinear model to verify the fact that farmers' income growth is lower than GDP growth, and puts forward corresponding countermeasures and suggestions to increase farmers' income.
\end{abstract}

Keywords-farmers' income; economic growth; logarithmiclinear model

\section{INTRODUCTION}

Farmers' income is not only related to the interests of farmers and rural development, but also directly related to the overall situation of social stability and national economic development. From the perspective of farmers' interests, raising their income is their greatest hope; from the perspective of rural development, backward rural public utilities are closely related to the lower level of farmers' income; in the view of national economy, if farmers' income fails to rise, rural purchasing power will not be improved, expanding domestic demand and developing the economy will be constrained. Farmers can't get rich, and the goal of building a well-off society in an all-round way can't be achieved eventually. Farmers' income is the key to resolve the problems of peasants, countryside and agriculture.
Therefore, it is still an important issue for to research to recognize the current situation of farmers' income and seek effective ways to increase farmers' income. The paper uses logarithmic-linear model to verify the fact that farmers income growth is lower than GDP growth, and puts forward corresponding countermeasures and suggestions to increase farmers' income.

\section{THE EMPIRICAL ANALYSIS}

Firstly, the paper studies the relationship between rural per capita net income and per capita GDP in Fujian province, in order to find out whether the growth of farmers' income lags behind the economic growth rate, or to what extent farmers can share the achievements of economic development. Therefore, the log-linear model is established, and the coefficients can directly show the relationship between rural per capita net income and GDP.

\section{$\operatorname{LnRYt}=\beta 1+\beta 2 \times \ln \mathrm{VDPt}$}

RY: rural per capita net income

VDP: per capita GDP

This paper uses the data from 1978-2009, all the data are from Fujian statistical yearbook (past), to eliminate price changes, the rural per capita net income eliminate the rural consumer price index, per capita GDP eliminate retail price index and all data are converted based on 1977. (See "Table I")

TABLE I. Fujian Rural PER CAPITA Net Income ANd Per CAPITA GDP

\begin{tabular}{|c|c|c|c|c|c|c|}
\hline Years & $\begin{array}{c}\text { Rural per capita } \\
\text { net income } \\
\text { (yuan) }\end{array}$ & $\begin{array}{c}\text { Per capita } \\
\text { GDP (yuan) }\end{array}$ & $\begin{array}{c}\text { Rural Consumer } \\
\text { Price Index (\%) }\end{array}$ & $\begin{array}{c}\text { Retail price } \\
\text { index (\%) }\end{array}$ & RY(yuan) & $\begin{array}{c}\text { VDP(100 } \\
\text { million) }\end{array}$ \\
\hline 1978 & 138 & 273 & 100 & 100 & 138 & 272 \\
\hline 1979 & 142 & 300 & 103 & 103 & 138 & 290 \\
\hline 1980 & 172 & 348 & 108 & 109 & 160 & 319 \\
\hline 1981 & 232 & 416 & 110 & 113 & 211 & 368 \\
\hline 1982 & 268 & 457 & 114 & 117 & 236 & 390 \\
\hline 1983 & 302 & 487 & 115 & 119 & 263 & 411 \\
\hline 1984 & 345 & 591 & 116 & 121 & 297 & 490 \\
\hline 1985 & 396 & 737 & 125 & 134 & 317 & 549 \\
\hline 1986 & 419 & 809 & 131 & 143 & 319 & 567 \\
\hline 1987 & 485 & 999 & 142 & 157 & 342 & 638 \\
\hline 1988 & 613 & 1349 & 179 & 199 & 343 & 676 \\
\hline 1989 & 697 & 1589 & 213 & 237 & 328 & 672 \\
\hline 1990 & 764 & 1763 & 210 & 233 & 365 & 756 \\
\hline
\end{tabular}




\begin{tabular}{|c|c|c|c|c|c|c|}
\hline Years & $\begin{array}{c}\text { Rural per capita } \\
\text { net income } \\
\text { (yuan) }\end{array}$ & $\begin{array}{c}\text { Per capita } \\
\text { GDP (yuan) }\end{array}$ & $\begin{array}{l}\text { Rural Consumer } \\
\text { Price Index }(\%)\end{array}$ & $\begin{array}{c}\text { Retail price } \\
\text { index }(\%)\end{array}$ & RY(yuan) & $\begin{array}{l}\text { VDP }(100 \\
\text { million })\end{array}$ \\
\hline 1991 & 850 & 2041 & 215 & 241 & 396 & 847 \\
\hline 1992 & 984 & 2557 & 223 & 254 & 441 & 1006 \\
\hline 1993 & 1211 & 3556 & 255 & 289 & 475 & 1229 \\
\hline 1994 & 1578 & 5193 & 320 & 356 & 493 & 1460 \\
\hline 1995 & 2049 & 6526 & 366 & 407 & 559 & 1603 \\
\hline 1996 & 2492 & 7646 & 386 & 425 & 646 & 1798 \\
\hline 1997 & 2786 & 8775 & 391 & 424 & 713 & 2067 \\
\hline 1998 & 2946 & 9603 & 389 & 418 & 757 & 2297 \\
\hline 1999 & 3091 & 10323 & 386 & 403 & 801 & 2559 \\
\hline 2000 & 3230 & 11194 & 391 & 399 & 826 & 2805 \\
\hline 2001 & 3381 & 11691 & 388 & 391 & 871 & 2990 \\
\hline 2002 & 3539 & 12739 & 387 & 384 & 913 & 3314 \\
\hline 2003 & 3734 & 14125 & 391 & 381 & 954 & 3708 \\
\hline 2004 & 4089 & 16235 & 408 & 391 & 1002 & 4150 \\
\hline 2005 & 4450 & 18353 & 420 & 394 & 1061 & 4663 \\
\hline 2006 & 4835 & 21105 & 421 & 396 & 1149 & 5336 \\
\hline 2007 & 5467 & 25582 & 444 & 413 & 1233 & 6201 \\
\hline 2008 & 6196 & 29755 & 464 & 436 & 1335 & 6823 \\
\hline 2009 & 6680 & 33437 & 454 & 427 & 1471 & 7832 \\
\hline 2010 & 7427 & 40025 & 470 & 441 & 1581 & 9067 \\
\hline 2011 & 8779 & 47377 & 495 & 463 & 1775 & 10241 \\
\hline 2012 & 9967 & 52763 & 506 & 471 & 1968 & 11204 \\
\hline 2013 & 11405 & 58145 & 518 & 476 & 2201 & 12212 \\
\hline 2014 & 12650 & 63472 & 528 & 481 & 2396 & 13186 \\
\hline 2015 & 13793 & 67966 & 537 & 481 & 2569 & 14134 \\
\hline 2016 & 14999 & 73951 & 545 & 484 & 2752 & 15271 \\
\hline 2017 & 16335 & 82677 & 549 & 487 & 2974 & 16971 \\
\hline
\end{tabular}

In this paper, Eviews 8.0 is used for regression analysis, and the results are shown in "Table II".

TABLE II. REGRESSION RESULTS

\begin{tabular}{|c|c|c|c|c|}
\hline Variable & Coefficient & Std. Error & t-Statistic & Prob. \\
\hline C & 1.463354 & 0.096725 & 15.12907 & 0.0000 \\
\hline LNX & 0.660331 & 0.012482 & 52.90098 & 0.0000 \\
\hline R-squared & 0.986603 & Log likelihood & 35.91846 \\
\hline $\begin{array}{c}\text { Adjusted R- } \\
\text { squared }\end{array}$ & 0.986251 & F-statistic & 2798.513 \\
\hline
\end{tabular}

According to the regression results, $\mathrm{R} 2=0.98$, close to 1 , shows the model fits well, and the variable LNX is equal to 0 , which is extremely significant. According to the regression results, the regression equation is:

\section{LNRY $=1.4633+0.6603 *$ LNVDP}

This coefficient is the elasticity of farmers' income to GDP, and the elasticity is less than 1 , indicating that the growth rate of farmers' income is less than the growth rate of GDP. For every $1 \%$ increase in per capita GDP, the per capita net income of farmers only increases by $0.63 \%$. This shows that although farmers' income is indeed increasing, it is lower than the average growth rate of the society. Moreover, with the increase of price level, farmers' income has increased in nominal terms, but the real purchasing power level has been declining. As a result, farmers have fallen into difficulties in life, especially in coping with the current medical treatment and education. So it is urgent and necessary to speed up agricultural development, promote agricultural efficiency and increase farmers' income

\section{CONCLUSION}

Firstly, it's a must to actively promote the urbanization process, and promote the combination of agricultural urbanization and industrialization. Agricultural industrialization is an important way to transform traditional agriculture into modern agriculture and the only way to solve China's agricultural problems. This also is a kind of effective new way that increases farmer income directly. At the same time, through the transfer of surplus rural labor to increase the income level of farmers indirectly.

Secondly, it's a must to invigorate the rural market economy, standardize the agricultural means of production market, and raise grain purchase prices. It is necessary to strengthen the assistance of departments, increase the financial support, control the operating threshold and strengthen market supervision. At the same time, it is necessary to establish and improve the resistance mechanism of business analysis in order to fight against illegal traders and standardize market order.

Finally, it's a must to cultivate new farmers with culture, technology and management skills, step up agricultural restructuring to replace the traditional agriculture with modern farming. Whether it is to develop agriculture or to promote the transfer of employment of farmers, it's needed to constantly improve the quality of farmers, take improving the comprehensive quality of farmers as the support point for the growth of farmers' income, and effectively strengthen the training of farmers. The government should instill farmers' scientific and technological concepts, change their educational ideas, organize various agricultural new technology extension classes in the countryside, improve the 
conversion rate of scientific and technological achievements, and benefit the local farmers in real terms.

\section{REFERENCES}

[1] Ju-Hong Bai. Analysis of the Relationship between Farmers' Income Level and Rural Human Capital [J]. Journal of Agrotechnical Economics, 2003(1):16- 18.

[2] Feng-Lian Tan, Yu-Wen Peng. Correlation Analysis of Urbanization, Economic Growth and Farmer Income [J].Journal of Hunan Agricultural University (Social Sciences), 2018, 19(05):94-100.

[3] Shan-Xu,Ya-Jun Xiong. Dynamic Analysis of Economic Growth and Farmers' Income - Take Hubei Province as an Example [J]. Henan Science, 2018,36(07):1111-1118.

[4] Zhi-Jun Zhang, Xiong-Jian Guo.Effects of Population Preferences Reversal on Income Growth of Rural Households - Based on the Analysis of Empirical Data of Farmers in Northwest China [J]. Fudan Journal(Social Sciences Edition), 2010(04):72-80.

[5] Hong-Lin Li, Qing-Lian LI, Juan Wang.Research on the Impact of Agricultural Technology Progress on Farmers' Income in Western Regions [J]. Ecological Economy ,2019,35(01):84-89. 